\title{
Integrated Hydrochemistry and Statistical Methods to Investigate Groundwater Origin and Salinization Process in Arid Regions (Central-eastern Tunisia)
}

\author{
Ali Souei ( $\nabla$ soueiali2014@gmail.com ) \\ Water Research and Technologies Centre Borj Cedria: Centre de Recherche et des Technologies des Eaux \\ de Borj Cedria https://orcid.org/0000-0001-7760-6367
}

\section{Fadoua Hamzaoui-Azaza}

Universite de Tunis El Manar Faculte des Sciences de Tunis

Taher Zouaghi

King Abdulaziz University Faculty of Earth Sciences

\section{Chafik Oueslati}

University of Tunis El Manar: Universite de Tunis El Manar

\section{Research Article}

Keywords: salinity, ion exchange, statistics PCA/HCA, Nadhour-Sisseb El-Alem

Posted Date: March 12th, 2021

DOI: https://doi.org/10.21203/rs.3.rs-276349/v1

License: (9) This work is licensed under a Creative Commons Attribution 4.0 International License. Read Full License 


\section{Abstract}

Hydrochemistry is a discipline widely used given the groundwater quantitative and qualitative reliability in the hydrogeological study. The geochemical study of groundwater in the Nadhour-Sisseb-El Alem basin aimed to characterize the water chemistry, determination of the physicochemical parameters and chemical facies well as and the mineralization processes. The Piper and Durov diagrams and scatter plots, conventional classification techniques, are applied to evaluate the geochemical processes. Samples are classified using two multivariate statistical methods, Principal Component Analysis (PCA) and Hierarchical Cluster Analysis (HCA). Waters compositions are affected by cation exchange reactions in the intercalated clay, resulting in a $\mathrm{Na}^{+}$increase, and peaks of $\mathrm{K}^{+}, \mathrm{Ca}^{2+}$ and $\mathrm{Mg}^{2+}$. $\mathrm{PCA}$ analyses show that the water samples have been classified into 8 groups. The waters quality deterioration is caused essentially by; overexploitation, decreased in freshwater recharge rates, climate condition; height evaporation low precipitation, artificial recharge by dam water, and irrigation return water.

\section{Introduction}

Groundwater, usually, is meteoric water stored in rock reservoirs. From their presence in atmosphere until their discharge (natural or artificial) and during stays in the reservoir, the water inherits the mineralogical and isotopic characteristic of the crossed environments (Mustafa et al., 2016, Mouna et al., 2017). The groundwater mineralization is affected by many factors; the natural processes (atmospheric input, the dissolution/precipitation, geology of the reservoir, groundwater recharge source and climate) and anthropogenic activities (agriculture, urbanization, industry) (Mouna et al., 2017). These factors lead to influence the initial chemical composition and hydrogeochemical groundwater facies (Ameur et al., 2015; Ameur et al., 2015; Hassen et al., 2015 and 2016, Alharbi et al., 2017; Jarray et al., 2017).

Increasing water demand, in arid and semi-arid regions due to agricultural, urban and industrial development, greatly stressed the water resources. The utility of water in drinking water, agriculture, domestic and industrial supply is related at the water quality (Ameur et al., 2015; Alharbi et al., 2017; Houatmia et al., 2015).

Groundwater in the south Mediterranean country is sensitive to climatic and anthropogenic hazards essentially the preponderance of the agricultural needs (Hassen et al., 2015 and 2016, Jarray et al., 2017, Ameur et al., 2015). In Tunisia, water resources were evaluated in 2000 to 4825 Mm3, with 2700 Mm3 of surface water and $2125 \mathrm{Mm} 3$ of groundwater (Jellalia et al., 2015). Indeed, Nadhour Sisseb El Alem region is characterized by a mean annual temperature of $20^{\circ} \mathrm{C}$ and a potential evapotranspiration of 1500 $\mathrm{mm} /$ year (INM, 2016). The mean annual precipitation is $350 \mathrm{~mm}$ indicating therefore a semi-arid climate (Souei, 2019). Study area is characterized by an absence of high mountains (Fig. 1). The study basin is considered among the important water reservoirs of the Central Tunisia (Fig.1). Water resources are used to satisfy the water demands of the Nadhour, Sisseb and El Alem regions and some cities of Sahel region, since the 70's. 
The large expansion of irrigated area and the unfavorable climatic conditions increase the demand for groundwater. Indeed the deep aquifer is considered the main source of freshwater for different purposes (Houatmia et al., 2016; Souei et al., 2018).

In the last decades the Nadhour Sisseb El Alem deep aquifer system has been subjected to overexploitation, caused by development of illicit well, consequently, a piezometric drop of $20 \mathrm{~m}$ apparent (Souei, 2019; Souei et al., 2018). In addition to the natural recharge, a process of artificial recharge by water from the dam is carried out to compensate the piezometric drop (Houatmia et al., 2015, Hamdi et al., 2017; Ibn Ali et al., 2017; Souei, 2019). Piezometric drop causes a perturbation of groundwater flow in the basin, reducing the communication between the aquifer units from upstream to downstream (Souei et al. 2018; Souei and Zouaghi 2018). In addition, the shallow aquifer has been abandoned due to the high salinity and the deepening of the water level (Souei et al., 2018; Souei, 2019). The freshwater resources of this basin are threatened by natural agents and human activities

Water management to conserve its quantity and quality has recognized supplemental attention in the last decades in the Nadhour Sisseb El Alem basin (Houatmia et al., 2015, Souei et al., 2016, Souei et al., 2018, Souei and Zouaghi, 2018). To investigate hydrochemical processes guiding the groundwater chemistry, ionic relationships plots, water facies diagrams, and Statistics analysis are used (Hamzaoui-Azaza et al., 2013; Tlili et al., 2013; Isawi et al., 2016).

Therefore, the chemical composition of the water and the mineralization process are affected by climate change and human activity. Study of the hydrochemical of water in the Nadhour-Sisseb-El Alem basin has numerous interests, in particular decrease the financial managment costs (annual cost of deepening wells, consumption increasingly important energy), prevent the water degradation and soil salinization, and improve the specific flow rates of wells. Knowledge of the hydrochemical process of groundwater in this area improved the use of groundwater and guiding the sustainable development of water resources and effective management.

The aim of this study was the determination of hydrochemical processes of groundwater, to clarify the relationship between the hydrogeological unit of the study area, to assess the effect of anthropogenic activity, and develop a conceptual model to support the management and development of water resources in the Nadhour Sisseb El Alem region.

\section{General setting}

The study area is characterized by a semi-arid Mediterranean climate, long dry periods, with an irregularity rainfall. The precipitation (2008-2009) show rainfall varies between a minimum of $150 \mathrm{~mm}$ characterizes the SW part of the basin and a maximum of $330 \mathrm{~mm}$ record at the center-east part of the basin (Fig. 1). Generally, rainfalls not exceed $400 \mathrm{~mm} /$ year at the northern zone and $300 \mathrm{~mm} / \mathrm{year}$ at the southern zone. 
The basin is characterized by insufficient sporadic flows and floods, produce rare torrential and turbid flows that lead generally to endorheic systems, lose themselves in often saline depressions. In the case of low flows, runoff water ends their cycle by evaporation at the El Alem, Bled Sadiaa and Bled El Ktifa plains and at Sebkhet El Kelbia, saline depression, when the flows are important (Fig. 1). The watershed contains many Surface water resources; four hill dams (Ogla, Sehel, Kseb and Saidaine), the great Nebhana Dam and more than 30 hilly lakes (Fig. 1). These resources are intended for aquifer recharge and irrigation. A large part of Nebhana dam is mobilized to supply irrigation water to some regions of the Sahel. The artificial recharge is done by spreading in the wadi bed.

Nadhour Sisseb-El-Alem basin includes multilayered aquifers (Figs. 2 and 3), composed by phreatic and deep groundwater stored in clastic Formations; Oligocene (Fortuna Formation), Miocene (Beglia and Saouaf Formation), Mio-Pliocene (Ségui Formation) and Quaternary filling (Figs. 2 and 3).

\section{Geology and structural framework}

The geology of the study area (Figs. 2 and 3) shows, that the basin is formed essentially by two collapsed structures.

The Nadhour-Saouaf syncline has N30 to N40 direction is occupied by quaternary deposits (Figs. 2 and 3). The central part of the SE flank is filed. The Mountains of the flanks of synclinal are formed by the Oligo-Miocene series, crossed by multi directional faults (Figs. 2 and 3). This structure is limited by several anticlines with a principal direction N040 (Fig. 1). The anticlines are occupied by Jurassic and Cretaceous series crossed by multi directional faults. Dextral and sinistral strike-slip faults limit these structures (Saadi, 1997).

The El Alem structure forms the southern area of the study basin (Figs. 2 and 3). It is characterized by a thick series of quaternary filling (Fig. 3). It is limited to the east by the Draa Es Souatir monoclinal (Fig. 1). This monoclinal is formed by Oligo-Miocene deposit, show an East dip (Fig. 3). The latter is covered by quaternary deposits, limited to the West by a NS sub-surface fault (Souei et al., 2018; Souei and Zouaghi, 2018). The Sbikha monoclinal is the western limit of El Alem basin, has submeridian direction (Fig. 2). Hydrological and petroleum drilling data show the presence of subsurface highest structure in the Sisseb region (Souei et al., 2018; Souei, 2019) (Fig. 3). A fled anticline structure set at the west of the Draa Es Souatir structure (Fig. 3) limits the basin to the east (Souei et al., 2018; Souei and Zouaghi, 2018).

The studied region contains outcrops corresponds from the Triassic (Rhetian) to Quaternary (Fig. 2). These show important thicknesses and lithologic variation. The felling is very thick in collapsed structures (Souei et al., 2018) (Figs. 2 and 3). The Triassic deposit is locally exposed in the massif of Jebel Fkirin and Jebel Zarss (Salaj et Stranik, 1970a,b; Mencik et al., 1978) (Fig. 2). The Triassic series are composed by clays, sandstone, gypsum and limestone facies (Mencik et al., 1978). Jurassic Formations are outcropping at Jebels Bent Saidaine, Fkirin and Zarss (Fig. 2). It composed of calcero-dolomitic series (Soussi, 2000). 
Cretaceous Formations are outcropping all along the fold structure of the basin (Fig. 2). Lower Cretaceous are formed by four Formations corresponding to the Berriasian-Valanginian Sidi Khalif Formation (clays, marl and limestones alternations), the Valanginian-Barremian M'cherga Formation (Alternations of clays, marl and limestones) (Mencik et al., 1978), the Barremian-Aptian Serdj Formations (limestone and marl) and the Aptian-Albian Fahdene Formations (shale and marl with some limestone) (Meddeb, 1986). The Cenomanian is composed of clays, marl and limestones alternations corresponding to Bahloul Formation (Burollet, 1956; Turki et al., 2002; Saadi, 1997). Kef Formation (TuronianCampanian) is composed of clay (Soussi, 2000). The late cretaceous (Campanien-Maastrichtien) is composed by the limestone bar of the Abiod Formation. The late Maastrichtian-Paleocene is represented by the El Haria formation which composed by marls and clays (Mencik et al., 1978). Eocene is subdivided into tow lithostratigraphic formations corresponding to the Ypresian Bou Dabous Formation (limestones) and the Lutetian Souar Formation formed by the marl, clay and limestone alternations (Burollet, 1956 ; Saadi, 1990 ; Lajnef et al., 2005) (Fig. 2).

The Oligocene-Aquitanian series (Fortuna Formation) is represented by sandstone, sand and clay with silt (Yaich, 1992) (Fig. 2). The Burdigalian characterized by pedogenic red silte with root. The Langhian formed by the lumachellic calcareous bar of the Ain Grab Formation (Fig. 2).

The Mahmoud Formation (Langhien supérieur) is composed by green clays. The Middle to Late Miocene series are composed by the Beglia (Serravallien moyen à supérieur) and the Saouaf (Serravallien Tortonien) Formations (Fig. 2). Beglia Formation is composed of coarse sands with quartz dragees (Saadi, 1997). Saouaf Formation is represented by thick detrital series with sands, clays and lignites, gypsum, marls and salts at the top) (Ben Moktar and Mannaï-Tayech, 2012). The Messinian-Pliocene (Segui Formation) starts with a polygenic conglomerate progressively transforming into clays and coarse sand finished by sandy-conglomerates bar (Salaj and Stranik, 1970 a, b; Mencik et al., 1978; Abbès and Boukadi, 1988) (Fig. 2).

\section{Hydrogeology}

From a hydrogeological point of view, the basin is formed by deep and phreatic water tables, (Houatmia et al., 2016; Souei, 2012; Souei et al., 2018; Souei, 2019) subjected to intense overexploitation. The aquifer system is composed of four hydrogeological units: Nadhour, Sisseb, El Alem and Etrabelsia (Souei et al., 2018). They are independent but interconnected (Souei et al., 2018; Souei, 2019). The Mio-Plio-Quaternary aquifer flows from the northwest to the southeast (Fig. 2) (Souei et al. 2018). To the north, in Nadhour region, the isopièze curves are tight indicating a high hydraulic gradient of 0.021. In Bled Sisseb and Etrabelsia regions, the spacing of isopièze curves is very important (Fig. 2). The hydraulic gradient is 0.001. Towards the south, in El Alem region, the curves become more spacing with a hydraulic gradient of 0.006 .

The water table stored in the Mio-Plio-quaternary deposit is characterized by transmissivity between 2.2 $10^{-3} \mathrm{~m}^{2} / \mathrm{s}$ and $8.510^{-3} \mathrm{~m}^{2} / \mathrm{s}$. The permeability values are between 0.34 and $3.3410^{-4} \mathrm{~m} / \mathrm{s}$. Aquifers are 
pumped up frequently with a flow rate between 5 and $20 \mathrm{l} / \mathrm{s}$. In particular, it is pumped up in the Zouagha, region, with a flow rate $55 \mathrm{l} / \mathrm{s}$. The rate of groundwater extraction increased from $11 \mathrm{Mm}^{3}$ in 1985 to $25 \mathrm{Mm}^{3}$ in 2012. Groundwater is extracted from deep borehole tapping the Mio-Plio-quaternary aquifer, ranging in depth from 100 to $400 \mathrm{~m}$. It is mainly consumed by the agricultural sector based on irrigated cultivation which consumes more than (89\%) of total pumped water (DGRE, 2013). $11 \%$ of pumped water is oriented to the drinking water supply (DGRE, 2013). The industrial sector consumes only 0.02 $\mathrm{Mm}^{3} /$ year (DGRE, 2013).

\section{Materials And Methods}

\section{Sampling and analytical procedure}

32 Samples were collected in May 2014, in 1 l polyethylene bottle. The bottles are well rinsed by the sampled water and totally refill to empty the area in the bottle (Fetter 1994; Appelo et Postma, 2005). The samples were filtered using a $0.45 \mathrm{~mm}$ cellulose acetate filter and refrigerated until the time of analysis (Eaton et al., 1995; Rodier, 2005). The samples were collected directly from the well after $10 \mathrm{~min}$ of pumping the well (Hamzaoui-Azaza et al., 2020). Sample locations were making using the Global Positioning System (GPS) with reference datum of WGS84. The Potential of hydrogen (PH), electrical conductivity (EC) and temperature was measured in situ using portable multi-parameter instruments WTW model 340i. Eleven variables (temperature [T, 6C], pH, total dissolved solids [TDS], HCO3-, Cl-, SO42-, $\mathrm{Na}+, \mathrm{K}+, \mathrm{Ca} 2+, \mathrm{Mg} 2+$ ) were determined from the water samples.

\section{Hydrochemical methods}

Thirty-two samples were selected for chemical analysis. They were shipped to the Géoressource Laboratory (GR.), at Water Researches and Technologies Center Borj-Cedria Technopark-Tunisia, which using the standard method (Rodier, 2005).

The total hardness was determined by complexometric titration with EDTA. EDTA acts as a complexion reagent which forms soluble complexes with metal ions such as $\mathrm{Ca}^{2+}$ and $\mathrm{Mg}^{2+}$. The $\mathrm{Ca} / \mathrm{Mg}$-EDTA complexes were stable at $\mathrm{pH} 8$ to 10 the $\mathrm{pH}$ of the solution during titration was maintained at 10 by addition of a buffer such as a solution of $\mathrm{NH} 4 \mathrm{OH}$ using an Eriochrome black indicator. $\mathrm{Ca}^{2+}$ and $\mathrm{Mg}^{2+}$ were determined by the titration method using standard EDTA. The chloride was determined by the selective electrode method. The alkalinity and total alkalinity are determined by titration the samples with the $\mathrm{HCl}$ solution using a phenolphthalein indicator and a methyl orange indicator. The carbonate and bicarbonate were determined from the alkalinity. The flame photometer method is used in the determination of $\mathrm{Na}^{+}$and $\mathrm{K}^{+}$concentrations. The concentration of nitrate $\left(\mathrm{NO}_{3}^{-}\right)$and nitrite $\left(\mathrm{NO}_{2}^{-}\right)$is determined by colorimetry with a UV-visible spectrophotometer.

We have retained 32 samples of the Mio-Plio-Quaternary aquifer to which chemical balances are acceptable (balances between \pm 5\%) (El Yaouti et al., 2009; Belkhiri et al., 2012; Choi et al., 2014; Najib et 
al., 2016).

Pie diagram, bivariate plots, Durov, Chadha and Piper plots are used in the determination of Groundwater facies classification and major processes control the global groundwater chemistry (Piper, 1944). The speciation code PHREEQC 2.8 is used in the calculation of the saturation indices of the principal mineral phases. Principal component analysis (PCA) and Hierarchical Cluster Analysis (HCA) are used to determine the classification of groundwater.

\section{Statistical analysis}

The graphical representation of the chemical elements and the study of characteristic ratios showed that a large number of chemical and physicochemical parameters were significant, taken individually (Hamzaoui et al., 2011). To explain the evolution of chemistry, most of the time one (or many), more or less strong link exists between these parameters. It was therefore interesting to try the data by statistical process, using a method of multivariate analysis as Principal Component Analysis (PCA). The intermediate correlation matrices and the projection of the variables in the space of the axes F1 and F2 were obtained with XLSTAT 2015 software.

PCA is a method of statistical study that allows the projection of observations into a space of a dimension smaller than the original space so that a maximum of information is conserved (Hamzaoui et al., 2011) (the information here is measured through the total variance of the point cloud) on the first dimensions. In our geochemical study, each water sample is a statistical observation. The various parameters subject to analysis constitute the variables which characterize these statistical units (Cloutier et al., 2008; Hamzaoui et al., 2011). Our present study focuses on the major elements (variable) that influence the evolution of mineralization (Davis, 1986).

The variables most contributing to the formation of an axis are those whose coordinates on this axis are close to 1 in absolute value. Similarly, the individuals contributing the most to the formation of an axis are those whose coordinates on this axis are the highest in absolute value.

The HCA is based on the Euclidean simple distance between various parameters (Ashley and Lloyd, 1978; Cloutier et al., 2008). It is used to classify water into groups. This classification is based on several methods in the present study we will use that of ward (Ward, 1963). Groups with a statistical relationship can have a significant hydrochemical interpretation (Hamzaoui-Azaza et al., 2020).

\section{Results}

In this part, we will try to identify the various geochemical phenomena that can occur within the aquifers studied. We will use, for comparison purposes, all the available data and some relationships between the main major elements leading to the acquisition of the water salinity. 


\section{Hydrochemical data}

Samples show a temperature varying between 22 and $31^{\circ} \mathrm{C}$ (Tab. 1). The $\mathrm{pH}$ values varied from 7.1 to 8.4 which lie in the range of neutral to slightly alkaline. These values vary indifferent of depth. The EC values range from 1333 to $3490 \mu \mathrm{S} / \mathrm{cm}$.

Pie diagram (Fig. 4a) of median values of major ions show the order of abundance in the groundwater is $\mathrm{Cl}^{>}>\mathrm{SO}_{4}{ }^{2-}>\mathrm{HCO}_{3}>\mathrm{Mg}^{2+}>\mathrm{Na}^{+}>\mathrm{Ca}^{2+}>\mathrm{K}^{+}>\mathrm{NO}_{3}{ }^{-}$. The $\mathrm{Cl}^{-}$and $\mathrm{Mg}^{2+}$ are the dominant anion and cation, with $24 \%$ and $16 \%$ respectively.

The results of the groundwater chemical analyze are plotted on the Piper diagram (Fig. 4b) using the " DIAGRAMMES » software (Simler, 2013). Piper diagram indicates a Ca-Mg-Cl-SO4 water facies (Fig. 4b). Durov and Chadha plots confirm that the groundwater type is Ca-Mg-Cl-SO4. The anion diagram shows that the majority of samples are characterized by a predominance of chlorides over the sulphates (Fig. 4b). The cation diagram shows the dominance of magnesium and relative dominance of sodium over the calcium (Fig. 4b). Dominance of $\mathrm{Ca}^{2+}$ and $\mathrm{Mg}^{2+}$ indicate that the water mineralization is affected by the inverse ion exchange process (Figs. 5 and 6). It's given by the exchange of $\mathrm{Ca}^{2+}$ from the matrix by the $\mathrm{Na}^{+}$from the groundwater (Escolero, 2005).

Samples were plotted on a Durov diagram (Fig. 5). Fresh water is indicated by samples located in the upper left corner, old water is indicated by samples located in the lower right corner (Appelo and Postma 2005). The Chadha diagram (Chadha, 1999) show that the samples of Fresh water is located in the upper right corner, old water is shown by samples located in the lower left corner (Melloul and Goldenberg, 1998). Greater parts of samples are located along the mixing path between fresh water and old water (Fig. 6). Other samples are located outside the mixing path (Fig. 6). We determine that groundwater is dominated by brackish water (Fig. 6). We conclude that the mixing process of fresh water and old water is not the only process that affects the groundwater quality in the study area.

The $\mathrm{Ca}^{2+}$ concentrations ranged from 32 to $541 \mathrm{mg} / \mathrm{L}$, with an average concentration of $105 \mathrm{mg} / \mathrm{L}$ (Tab. 1). The average concentration of $\mathrm{HCO}_{3}{ }^{-}$is $250 \mathrm{mg} / \mathrm{L}$, with a maximum of $760 \mathrm{mg} / \mathrm{L}$ (Tab. 1).

The correlation between calcium and bicarbonate (Fig. 7) shows that the majorities of the samples are above the line of carbonate dissolution (slope 1). The $\mathrm{Mg}^{2+}$ concentrations ranged from 85 to $491 \mathrm{mg} / \mathrm{L}$, with an average concentration of $281 \mathrm{mg} / \mathrm{L}$ (Tab. 1). However, water has an excess of $\left(\mathrm{Ca}^{2+}+\mathrm{Mg}^{2+}\right)$ versus to $\mathrm{HCO} 3$ (Fig. 7). $\mathrm{SO}_{4}{ }^{2-}$ concentrations ranged from 44 to $1328 \mathrm{mg} / \mathrm{L}$, with an average of 395 $\mathrm{mg} / \mathrm{L}$. Chloride $\left(\mathrm{Cl}^{-}\right)$shows high values ranging from 135 to $754 \mathrm{mg} / \mathrm{L}$ (Tab. 1).. Nitrate $\mathrm{NO}_{3}{ }^{-}$ concentrations range from 0 to $29 \mathrm{mg} / \mathrm{L}$ (Tab. 1). The nitrite NO2 concentrations range from 0 to 0.39 $\mathrm{mg} / \mathrm{l}$ (Tab. 1).

\section{Correlation matrix}


Examination of the correlation matrix shows a weak correlation between the variables. We note the presence of only four correlations of absolute value greater than 0.5 (Tab. 2).

The proper value obtained for the factorial axes shows that there are three axes to be used (Tab. 3). The two factorial axes F1 and F2 are contribution of the total information of $49.42 \%$, due to inertia of $27.73 \%$ and $21.69 \%$ respectively for $\mathrm{F} 1$ and $\mathrm{F} 2$. The factorial plane $\mathrm{F} 1-\mathrm{F} 3$ represents $37.99 \%$ of the total variance.

The projection of the variables on the factor plane F1-F2 (Fig. 8) shows that the F1 axis is determined by the total salinity (0.836), calcium (0.582), sodium (0.478) and sulphate $(0.254)$ (Tab. 3 ). It thus contrasts mineralized waters with weakly charged waters (Fig. 8). The vertical factor F2 is defined by potassium $(-0.633)$ and bicarbonate $(0.437)$. The F3 factor $(13.26 \%)$ is represented by chloride $(0.645)$ and magnesium (0.538) (Tab. 3) shows an opposition between the water rich in magnesium and chloride and waters weakly charged in these elements (Fig. 8).

\section{Discussions}

This excess of $\mathrm{Ca}^{2+}$ ions has other origin than the dissolution of carbonates, which is probably the dissolution of gypsum or the inverse ion exchange of $\mathrm{Ca}^{2+}$ ions in favor of $\mathrm{Na}^{+}$ions (Fig. 9a) and by infiltration of the storm water coming down from the cretaceous Formation. Magnesium of carbonate origin can be mobilized, in small portions, by the waters of the surfaces during leaching of the carbonate outcrops (Cretaceous and Eocene). Raised concentrations in $\mathrm{Mg}^{2+}$ are an indicator of the presence of return water irrigation. Salt water irrigation causes soil fertilization by the inverse ion exchange between $\mathrm{Mg}^{2+}$ and $\mathrm{Na}^{+}$. The presence of bicarbonates in water is due to the dissolving of the carbonate rocks (Fig. $9 \mathrm{~b}$ ) of post-Oligocene Formations, which borders the region, on the one hand, and leaching of the OligoMiocene Formation (carbonate sandstone) on the other hand.

However, this excess of $\left(\mathrm{Ca}^{2+}+\mathrm{Mg}^{2+}\right)$ versus to $\mathrm{HCO} 3$ could be the result of the basic exchange process (Fig. 9a). The presence of sulphates in water is related to the dissolution of the gypsum derived from MioPlio-Quaternary outcrop. The correlation between $\mathrm{Ca}^{2+}$ and $\mathrm{SO}_{4}{ }^{2-}$ shows an excess of $\mathrm{SO}_{4}{ }^{2-}$. This calcium deficiency may be related; Either to the precipitation of calcite or to the base exchange of $\mathrm{Ca}^{2+}$ ions in favor of $\mathrm{Na}^{+}$and $\mathrm{Mg}^{2+}$ between groundwater and the clay layers (Fig. 9a). The excess of $\mathrm{Cl}^{-}$versus to $\mathrm{Na}^{+}$ can be reported to the infiltration of the evaporated water dam (Zammouri and Feki, 2005), which is relatively more salty (Kacem, 2008). During the infiltration of the dam water the $\mathrm{Na}^{+}$ions are adsorbed and $\mathrm{Cl}^{-}$ions released, which explains the excess in chlorides. The $\mathrm{Na}^{+}$concentrations range from 22 to 97 $\mathrm{mg} / \mathrm{L}$, with an average of $48 \mathrm{mg} / \mathrm{L}$ (Tab.1).

The $\mathrm{Cl} /(\mathrm{Na}+\mathrm{K})$ ratio (Fig. 10a) illustrates three groups of waters. Samples aligned along the line of slope 1 highlighting the effect of halite dissolution, this group is weakly represented in the studied area. Samples plot in a mixing position this can only be explained by the mixing between the deep waters and the freshwater waters, this type of waters represented by the majority of the samples. Evaporation has possible to have manifest on surface water or shallow groundwater. The third group shows an excess of 
$(\mathrm{Na}+\mathrm{K})$ indicate the base ion exchange, it is weakly represented in the studied area. The Potassium probably results from the dissolution of chemical fertilizers (NPK) (Kacem et al., 2008; Farid et al., 2015; Haouatmia, et al., 2016), the Base Exchange processes in clays, and the dissolution of chloride in potassium (KCl). The $\mathrm{K}^{+} / \mathrm{Cl}^{-}$ratio (Fig. 10b) shows an excess of $\mathrm{Cl}^{+}$versus to $\mathrm{K}^{+}$thus demonstrating the mixing effect between the deep waters and the surface waters. $\mathrm{Na}^{+}$and $\mathrm{Cl}^{-}$ions in the rural regions are habitually resulting from chemical fertilizers and animal waste (Rodvang et al., 2004).

The natural concentration of nitrate NO3 in groundwater is habitually very low (typically less than 10 $\mathrm{mg} / \mathrm{l})$ (USEPA, 1987), although nitrate concentrations is amplify among, agriculture and industry activity and the domestic effluents. Even if they are very low NO3 concentrations in groundwater can confirm the hypothesis of return flow irrigation waters (Stewart and Aitchison-Earl, 2020).

Results obtained from PCA shows there is a good correlation between total salinity and chloride, sodium, sulphate, magnesium and calcium. Other less significant correlations between the electrical conductivity and the bicarbonates (Tab. 3) deduced that the water salinity is due to salt formations such as gypsum, anhydrite and halite. This tendency is confirmed by the good correlation between the sulphates and the calcium of one part and between the sodium and the chloride of another part.

There is a good positive correlation between total salinity and magnesium on the one hand and total salinity and sodium on the other hand (Tab. 4). Correlation matrix shows a lower correlation between sodium and chloride. These two positive correlations between TDS/ $\mathrm{Na}$ and $\mathrm{Na} / \mathrm{Cl}$ indicate a high participation of halites in the mineralization of water. However, the low correlation between TDS/CI indicates another source of $\mathrm{Cl}^{-}$than dissolution of halite that may be due to the effect of evaporation.

Based on the results of the PCA (Fig. 11) we found that 2014 individuals "observation" are grouped into 8 groups. These eight groups describe the spatial evolution of water mineralization as one flow to the accumulation zone.

Gl: This group is represented by four samples; F9, F10, F11 and F12 (Fig. 11) the first sample is taken from wadi Nebhana, however the last three constitute the water of the western part of the deep groundwater of Sisseb. The grouping of these samples in the same pole, high mineralization (Fig. 11), indicates that Sisseb groundwaters may be coming from a common source. Almost similar concentration of the elements of this group, probably related to recharge by the salty waters of Nebhena dam.

GII: Presence of this group in this intermediate position (Fig. 11) between shallow waters (GI) and the deep waters of El Alem region (GIV) is probably due to the discharge of the Nabhena River in the El Alem plain. This shows the importance of the Nabhena River in the recharge of this aquifer.

GIII: Represents the groundwater of Sbikha region. The Sbikha aquifer is largely recharged by the rainwater. The position of this group in the diagram shows the role of the Miocene outcrops in the recharge of the aquifer (Fig. 11). 
GIV: The group represented by F1, F2, F7 and F8 individuals is characterized by low mineralization (Fig. 11). It defined the deep aquifer of the El Alem region. These waters have possibly tow origin; infiltration of the water of the Nebhena dam (GI) and vertical drainage by the Sbikha and Sisseb groundwaters (GIII). The vertical drainage is essentially due to the piezometric level decrease.

GV: This group is represented by a single, representative, sample of water from the western region of Nadhour, is the most freshwater of this basin.

GVI: The projection of samples (F27, F28, F29, F31 and F32) on the factorial plane F1/F2 (Fig. 11) shows that the waters of the eastern Nadhour area (GVI), are highly mineralized and low charged by potassium and bicarbonate (Fig. 11). The high mineralization maybe due to the alimentation of the latter by the waters of dam, relatively more salted. This water is mixed with water of western Nadhour (GV) to give the water of the group GVII (Fig. 11).

GVII: The representation of the samples from the group, on the factorial plane F1/F2 (Fig. 11) shows that are in an intermediate position between the waters of Western Nadhour group GV, low mineralization and waters Oriental Nadhour Group GVI highly mineralized. This proves that the waters of Sisseb area are probably the result from mixture groups GV and GVI. The geographical location of this area in the downstream from Nadhour basin (Fig. 11), confirms the result deducted from the PCA. Water of the Sisseb group GVII is mixture water resulting from the dilution of the water from group GVI and the concentration of waters from Group GV.

GVIII: Waters of this group GVIII occupy a middle position on the factorials plane diagram F1/F2, between different groups, because their different origins (Fig. 11). The geochemical evolution of waters in the basin demonstrates that this group located at the downstream, presents the accumulation area of deep water from the basin. The waters from the group GVIII is alimented by the waters of the group GVII flow from the North and the waters from group GI derived from Nebhena dam flow from the west.

The statistical method (PCA) shows that the Sisseb region is a junction through which many came from waters represent by the three groups GI, GV and GVI. The waters of Nebhena (GI) percolation into aquifers in the Sisseb area towards the SE direction; followed the natural stream wadi Nebhana and progressively percolation towards the El Alem aquifer of the South; followed the diverted wadi Nebhana to Sbikha. The deep aquifer of El Alem is recharged by Nebhena water percolation from the North and horizontal percolating from the waters of the Sbikha deep aquifer came from the west.

The hierarchical classification (Fig. 12) of the samples shows that the waters of the basin are divided into two groups: - A first group is presented by thirteen samples: S1, S2, S4, S5, S6, S7, S8, S9, S10, S11, S12, S15 and S17. This group formed the first major groundwater flow direction between the GI, GII and GIV groups; water move from the Sidi Neji region toward the El Alem. - A second group presented by the other samples: S3, S13, S14, S16, S18, S19, S20, S21, S22, S23, S24, S25 S26, S27, S28, S29, S30, S31 and S32 (Fig. 12). These groups present the second main direction of groundwater flow between groups GIII, GV, GVI, GVII and GVIII; the water moves from the upstream side of the basin, Nadhour region, towards Bled 


\section{Mineralization conceptual model of groundwater in the Nadhour-Sisseb-El Alem basin}

The $\mathrm{Ca}^{2+}$ comes from leaching of the Jurassic, Cretaceous and Eocene carbonate outcrops and Triassic gypsum outcrops (Fig. 13). The decrease in $\mathrm{Ca}^{2+}$ with the flow direction may be related to the precipitation of $\mathrm{Ca}^{2+}$ of calcite and of Base Exchange.

The decrease in $\mathrm{Mg}^{2+}$ with the flow direction (Fig. 13) is an indicator that the $\mathrm{Mg}^{2+}$ is imported by inverse ion exchange; surface water and rainwater enrichment in $\mathrm{Mg}^{2+}$ during the infiltration and recharge by surface waters initially loaded by the $\mathrm{Mg}^{2+}$ (Kacem , 2008) comes from leaching of the Cretaceous and Eocene outcrops (Fig. 13). This will have a vertical enrichment during the infiltration process and lateral discharge during lateral flow (Fig. 13). In the first phase is the dissolution of $\mathrm{Mg}^{2+}$ by the runoff water and enrichment by the inverse ion exchange during flow and infiltration the second phase is the decrease of $\mathrm{Mg}^{2+}$ by the Base Exchange process and the precipitation of $\mathrm{Mg}^{2+}$ as aragonite and calcite.

Bicarbonates $\mathrm{HCO}$ in water is due to the dissolving of the carbonate and carbonate-sandstone rocks which borders the region (Fig. 13). The sulphate in water is probably related to the dissolution of the gypsum derived from Triassic, Eocene and Mio-Plio-Quaternary outcrop. The excess of $\mathrm{SO}_{4}{ }^{2}$ is related to the evaporation of surface and shallow groundwater. Chloride $\left(\mathrm{Cl}^{-}\right)$is derived from dissolution of the gypsum derived from Triassic, Eocene and Mio-Plio-Quaternary outcrop. Enrichment by $\mathrm{Cl}^{-}$reported to the evaporation of water dam and shallow groundwater (Fig. 11). The Potassium outcome from the alteration of Eocene and Miocene clays, the dissolution of NPK artificial fertilizers and the dissolution of chloride in potassium $(\mathrm{KCl}) . \mathrm{Na}^{+}$and $\mathrm{Cl}^{-}$ions are generally resulting from synthetic fertilizers and animal waste. The excess of $(\mathrm{Na}+\mathrm{K})$ is related to the Base Exchange.

The recent deterioration of the waters quality caused by overexploitation, decreased fresh water recharge rates, climate condition; height evaporation low precipitation, artificial recharge by dam water, and irrigation return water the intensive use of chemical fertilizers. Climate change and exhaustive groundwater mobilization, although supplying the water requirements in drinking water, agriculture, industry and tourism, with are the origins of depletion and deterioration of water quality and piezometric level increase in this basin.

\section{Conclusions And Perspectives}

The groundwater hydrochemical analysis in this region helped to identify and characterize the mineralization processes of groundwater. The mineralization groundwater of the aquifer system is guided 
by several processes the most important of is minerals dissolution/precipitation process, in a less important order the ion-exchange, and water mixing process with low intervention. The hydrogeochemical and statistical methods present the main tools used in the identification of these processes.

Based on PCA analysis, of recent data, 8 groups of samples have been assigned. group I: includes 4 wells with high salinity and high concentration of $\mathrm{Cl}^{-}$and $\mathrm{Mg}^{2+}$, groups II and III includes 3 and 2 wells respectively has shown moderate salinity and moderate concentration of $\mathrm{Cl}^{-}$and $\mathrm{Mg}^{2+}$, groups IV (4 wells) and $\mathrm{V}$ (one well) had lowest concentrations of ions and classified as freshwater, wells with moderate concentration of $\mathrm{Cl}^{-}$and $\mathrm{Mg}^{2+}$, group $\mathrm{Vl}$ : includes 6 wells with moderate salinity and low concentration of $\mathrm{Cl}^{-}$and $\mathrm{Mg}^{2+}$, group VII: includes 5 wells with moderate salinity and low concentration of $\mathrm{Cl}^{-}$and $\mathrm{Mg}^{2+}$, group VIII: includes 6 wells with moderate concentrations of ions and moderate low concentration of $\mathrm{Cl}^{-}$and $\mathrm{Mg}^{2+}$, and Group VIII ( 6 wells) showed intermediate salinity between this groups. Water samples in groups IIII, and VI present higher salinity compared to other groups. his shows that the water quality of groups II, IV, V, VII, and VIII is slowly getting to degradation. Processes mineralizations are accelerate by the constant increase of extraction rates and artificial recharge with dam water, relatively most charged.

The various analyses techniques used in this study confirmed that the deterioration of groundwater quality in this basin due to the anthropogenic activities; overexploitation, artificial recharge, water irrigation return... This anthropogenic activities are amplified by climate change; low precipitation, height evaporation rat.

Groundwater deterioration could be reduced by the decreasing pumping rates, limited number of well by creation of public irrigate area, management of recharge area by implantation of tree, management in the wadi bed, constructing more wells in bordure of basin, in this area water is more fresh; rapid infiltration. Decreases the storage period of water, intended to the artificial recharge, in dams. Mobilizes drinking water from boreholes locates near to the recharge areas.

\section{Declarations}

\section{Acknowledgements}

This research work was performed the Center for Research and Water Technologies (CERTE), Borj Cédria Technopole. It is a part of the Project "Characterization and evaluation of hydrogeological reservoirs in the Sahel-Kairouan basin, central-eastern Tunisia" which is funded by the Secretarial of Scientific Research and Technology (SERST) of Tunisia. The General Directorate of Water Resources (DGRE) and the Regional Office of Agricultural Development (CRDA) of the Kairouan and Zaghouan Governorate, are acknowledged for providing data and field logistic support.

\section{References}


1. Abbès, C., Boukadi, N., 1988, Sur la chaîne N-S de la Tunisie centrale et ses inflécissements d'axes. Analyse des déformations du noeud tectonique du jebel Ech Chérichira. Coulissement, blocage et rotation. Comptes Rendus de l'Académie des Sciences, France, 307, 1277-1282.

2. Alharbi OA, Allafouza Loni O, Zaidi FK ., 2017, Hydrochemical assessment of groundwater from shallow aquifers in parts of Wadi Al Hamad, Madinah, Saudi Arabia Arab J Geosci (2017) 10: 35 DOI 10.1007/s12517-016-2805-z

3. Ameur M, Hamzaoui-Azaza F., Gueddari M., 2015, Nitrate contamination of Sminja aquifer groundwater in Zaghouan, North-East Tunisia: WQI and GIS assessments: Desalination and water treatment journal. doi: 10.1080/19443994.2015.1137495.

4. Appelo C.A.J. et Postma D., 2005, Geochemistry, groundwater and pollution (2nd ed., p. 321). Rotterdam: Balkema.

5. Ashley, R. P. and Lloyd, J. W., 1978, An example of the use of factor analysis and cluster analysis in groundwater chemistry interpretation: Journal Hydrology, Vol. 39, pp. 355-364.

6. Ben Moktar, N. \& Mannaï-Tayech, B., 2012, Reconstitution de la végétation et du climat durant le Miocène dans le bassin de Saouaf (Tunisie centro-nord-orientale). Geodiversitas 34 (2): 445-456. http://dx.doi.org/10.5252/g2012n2a11.

7. Burollet, P. F., 1956, Contribution à l'étude stratigraphique de la Tunisie centrale. Ann Mines et Géol Tunis 18, Tunisie, $350 \mathrm{p}$.

8. Burollet, P. F., 1973, Importance des facteurs salifères dans la tectonique tunisienne. Livre Jubilaire M. Solignac. Ann Mines et Géol Tunis 26, pp. 110-120.

9. Chadha, D. K., 1999, A proposed new diagram for geochemical classification of natural waters and interpretation of chemical data. Hydrogeol. J., 7, 5, 431-439.

10. Cloutier, V., Lefebvre, R., Therrien, R. and Savard, M.M ., 2008, Multivariate statistical analysis of geochemical data as indicative of the hydro-geochemical evolution of groundwater in a sedimentary rock aquifer system. J. Hydrol.., 353, 294-313.

11. Davis, J. C., 1986, Statistics and data analysis in geology. New York: Wiley. 224 p.

12. Eaton, A.D., Clesceri, L.S., Greenberg, A.E., 1995, Standard methods for the examination of water and wastewater (19th ed.). Washington DC: American Public Health Association.

13. Escolero O; Marín LE; Steinich B; Pacheco JA; Molina-Maldonado, A; Anzaldo J. M. (2005) Geochemistry of the hydrogeological reserve of Mérida, Yucatán, Mexico Geofísica Internacional (2005), Vol. 44, Num. 3, pp. 301-314

14. Fetter, C. W., 1994, Applied hydrogeology (3rd ed.,p. 310). New York: Macmillan College Publication.

15. Hamzaoui-Azaza, F., Ameur, M., Chaouch, R., Ben Cheikha, L.,Gueddari, M., \& Carrillo-Rivera, J., 2020, Assessment of groundwater quality based on GIS and geochemical methods: coastal aquifer of Bouficha (North-Eastern Tunisia). Journal of Coastal Conservation, 24, 45. https://doi.org/10.1007 /s11852-020-00762-8. 
16. Hamzaoui-Azaza, F., Ketata, M., Bouhlila, R., Gueddari, M., \& Riberio, L., 2011, Hydrogeochemical characteristics and assessment of drinking water quality in Zeuss-Koutine aquifer, southeastern Tunisia. Environmental Monitoring and Assessment, 174, 283-298. https://doi.org/10.1007/s10661010-1457-9.

17. Hamzaoui-Azaza F., Tlili B., Bouhlila R. et Gueddari M, 2013, An integrated statistical methods and modeling mineral-water interaction to identifying hydrogeochemical processes in groundwater in Southern Tunisia. Chemical and Bioavailability Speciation, 25(3), pp165-178.

18. Hassen I., Hamzaoui-Azaza F, Bouhlila R., 2015, Application of Multivariate statistical Analysis, Hydrochemical and Isotopic Investigations for evaluation of groundwater quality and its suitability for drinking and agriculture purposes: Case of Oum Ali Thelepte Aquifer, Central Tunisia", Environmental Monitoring and Assessment : 188:135 DOI 10.1007/s10661-016-5124-7

19. Hassen I., Gibson E., Hamzaoui-Azaza F, Bouhlila R., 2016, 3D geological modeling of the Kasserine Aquifer System, Central Tunisia: New insights into aquifer-geometry and interconnections for a better assessment of groundwater resources. Journal of Hydrology 539 ·DOI: 10.1016/j.

20. Institut National de la Météorologie (INM)., 2016, Données Météorologique des stations de Kairouan et Zaghouan.

21. Isawi H., Magdi H. El-Sayed \& Mustafa Eissa \& Orfan Shouakar-Stash \& Hosam Shawky \& Mohamed S. Abdel Mottaleb., 2016, Integrated Geochemistry, Isotopes, and Geostatistical Techniques to Investigate Groundwater Sources and Salinization Origin in the Sharm EL-Shiekh Area, South Sinia, EgyptWater Air Soil Pollut (2016) 227: 151 DOI 10.1007/s11270-016-2848-5

22. Jarray H, Zammouri M, Ouessar M, Hamzaoui-Azaza F, Barbieri M, Zerrim A, Soler A and H Yahyaoui H., 2017, Groundwater vulnerability based on GIS approach: Case study of Zeuss-Koutine aquifer, South-Eastern Tunisia: Geofísica Internacional 56-1: 7-12

23. Jellalia D; Lachaal F, Andoulsi M, Zouaghi T, Hamdi M, Bedir M ., 2015, Hydro-geophysical and geochemical investigation of shallow and deep Neogene aquifer systems in Hajeb Layoun-JilmaOuled Asker area, Central Tunisia. Journal of African Earth Sciences 110 (2015) 227-244.

24. Lajnef, B., LE Callonnec L., Yaich C., Renard M., Benzarti R., 2005, L'intervalle Paléocène supérieur Eocène inférieur sur un profil de la Tunisie centro-septentrionale : approches sédimentologique et chimiostratigraphique.Bulletin de I'Institut Scientifique, Rabat, section Sciences de la Terre, 2005, $\mathrm{n}^{\circ} 27,17-27$.

25. Meddeb, S., 1986, Sédimentation et tectonique polyphasée dans les dômes d’Enfidha (sahel tunisien). Thèse de doctorat, p20-p30, p62.

26. Melloul and Goldenberg., 1998, Early-indicator signals of groundwater contamination: the case of seawater encroachment. Geol., 33, 4, 279-288.

27. Mencik, E., Stranik, Z., Solaj, J., 1978, Notice explicative de la feuille du J.Fkirine au 1/50000, édition service, Géologique Tunisie 62p.

28. Mouna M; Redouane CA ; Lhoussaine B ; Yassine AB ; Abdelaziz H; Reichert B ., 2017, Evolution of groundwater quality in intensive agricultural zone: case of Chtouka-Massa Aquifer, Morocco Arab J 
Geosci (2017) 10: 35 DOI 10.1007/s12517-016-2805-z

29. Mustafa 0 ; Tichomirowa M; Kummer1 NA; Broder Merkel B., 2016, Assessment of water-rock interaction processes in the Karst Springs of Makook Anticline (Kurdistan Region, Iraq) using Srisotopes, rare earth, and trace elements Arab J Geosci (2016) 9: 368 DOI 10.1007/s12517-016-23447

30. Piper, A. M., 1944, A graphic procedure in the geochemical interpretation of water analyses Trans. Geophys. Union 25, pp. 914-923.

31. Rodier J ., 2005, L'analyse de l'eau: Eaux naturelles, eaux résiduaires, eaux de mer. Edition Dunod, $1381 \mathrm{p}$.

32. Saadi, J., 1990, Exemple de sédimentation syntectonique au Crétacé inférieur le long d'une zone de décrochement NS. Les structures d'Enfidha (Tunisie nord-orientale) Géodynamique 5 (1). : 17-33.

33. Saadi, M., 1997, Géodynamique des bassins sur relais de décrochement au Crétacé-Cénozoïque et Géométrie des Séquences Génétique du Bassin Oligo-Aquitanien de Saouaf. Tunisie centro-orientale, Thèse Doctorat en géologie. Université, de Tunis II fac, de Science. 348p.

34. Salaj, J., Stranik, Z., 1970a, Rhétien dans I'Atlas tunisien oriental Notes du Ser. Géol. n³2, pp.37-44, 2pls.

35. Salaj, J. \& Stranik, Z., 1970b, Contribution à l'étude stratigraphique du Miocène du synclinal de Saouaf (région du J. Fkirine, Tunisie orientale). Notes du Service géologique de Tunisie 3: 79-82.

36. Simler, R., 2013, Logiciel d'hydrochimie. Diagrammes. Laboratoire d'Hydrogéologie d'Avignon.

37. Souei, A ., 2012, Caractérisation géophysique et hydrogéologique des systèmes aquifères du bassin de Sisseb-El Alem ; Tunisie Centro-orientale. Mémoire de master en Géologie. Université de Tunis El Manar II, Tunisie : 132p.

38. Souei, A and Zouaghi, T ., 2016, Utilisation du SIG pour la gestion intégrée des ressources en eau dans la région de Tunisie Centro-oriental : Kairouan Nord. Journées scientifiques de la Medjerda. Conference Paper.

39. Souei, A., Mhimdi, S., Zouaghi, T ., 2017, Extraction par télédétection des réseaux des fractures dans la région de Sisseb-El Alem ; Kairouan nord ; implication hydrogéologique. Book of Abstracts AGIC / The 1st Atlas Georesources International Congress, March 20-22. Hammamet -Tunisia, p310.

40. Souei, A., Atawa, M., Zouaghi T ., 2018, Hydrogeological framework and geometry modeling via joint gravity and borehole parameters, the Nadhour-Sisseb-El Alem basin (central eastern Tunisia). Journal of African Earth Sciences, 139: 133-164

41. Souei, A and Zouaghi, T., 2018, 2D seismic reflection contribution to structural and geometric study of Cenozoic aquifer systems in the Sisseb El-Alem basin,central-eastern Tunisia. Arabian Journal of Geosciences. 11:689. https://doi.org/10.1007/s12517-018- 4036-y.

42. Souei, A ., 2019, Apport de la géophysique, de la télédétection, des SIG, et de l'hydrochimie à l'étude hydrologique et hydrogéologique des systèmes aquifères du bassin de Nadhour-Sisseb-El Alem; Tunisie centro-orientale. Thèse de Doctorat, Université de Tunis-El Manar, 333 p. 
43. Soussi, M., 2000. Le Jurassique de la Tunisie Atlasique: Stratigraphie, Dynamique sédimentaire, Paléogéographie et Intérêt pétrolier. Thèse Doct. D’Etat En Science Géol. Université Tunis El Manar II, Tunisie 661p.

44. Stewart, MK and Aitchison-Earl, PL., 2020, Irrigation return flow causing a nitrate hot spot and denitrification imprints in groundwater at Tinwald, New Zealand. Hydrology and Earth System Sciences 24(7):3583-3601, DOI: 10.5194/hess-2020-58

45. , 1987, Estimated national occurrence and exposure to nitrate and nitrite in public drinking water supplies. Washington, DC, United States Environmental Protection Agency, Office of Drinking Water.

46. Tlili B., Hamzaoui-Azaza F., Gueddari M et Bouhlila., 2013, Geochemistry and water quality assessement of groundwater using graphical and multivariate statistical methods. a case study: Grombalia phreatic aquifer (North East of Tunisia). Arabian Journal of Geosciences.(6), pp35453561 .

47. Turki, M.M ., Saadi, M., Zaghabib, D. , Turki et Rami, A., 2002, Notice explicative des les feuille de Djebibina et Ain Jelloula au 1/50000, édition service, Géologique Tunisie.54p.

48. WARD, J. H., 1963, Hierarchical grouping to optimize an objective function. Am. Statist. Assoc., Vol. 58, pp. 236-244.

49. Yaich, C., 1992, Dynamic des faciès détritiques oligo-miocènes de Tunisie. Journal of African Earth Sciences. Paris, 15, 1, 35-47.

\section{Tables}

Tab.1 statistical data of the water samples

\begin{tabular}{|llllllllllll|}
\hline & TDS & $\mathrm{T}^{\circ} \mathrm{C}$ & $\mathrm{EC}$ & $\mathrm{Ca}$ & $\mathrm{Mg}$ & $\mathrm{Na}$ & $\mathrm{K}$ & $\mathrm{HCO3}$ & $\mathrm{Cl}$ & $\mathrm{SO4}$ & $\mathrm{NO3}$ \\
\hline MEAN & 2535 & 26 & 1945 & 105 & 281 & 212 & 48 & 250 & 411 & 395 & 8,9 \\
\hline STANDARD & 585 & 25 & 496 & 115 & 86 & 110 & 16 & 106 & 135 & 320 & 8,5 \\
DEVIATION & & & & & & & & & & & \\
MIN & 585 & 25 & 496 & 32 & 85 & 58 & 16 & 106 & 135 & 44 & 0,00 \\
MAX & 4270 & 31 & 3490 & 541 & 491 & 467,8 & 97,9 & 760 & 754 & 1328 & 29 \\
\hline
\end{tabular}

Tab. 2 correlation matrix 


\begin{tabular}{|lllllllll|}
\hline & TDS & $\mathrm{Ca}$ & $\mathrm{Mg}$ & $\mathrm{Na}$ & $\mathrm{K}$ & $\mathrm{HCO} 3$ & $\mathrm{Cl}$ & $\mathrm{SO} 4$ \\
\hline $\mathrm{TDS}$ & $\mathbf{1}$ & & & & & & & \\
\hline $\mathrm{Ca}$ & $\mathbf{0 , 2 3 0}$ & $\mathbf{1}$ & & & & & & \\
\hline $\mathrm{Mg}$ & $\mathbf{0 , 6 4 3}$ & $\mathbf{0 , 0 2 5}$ & $\mathbf{1}$ & & & & & \\
\hline $\mathrm{Na}$ & $\mathbf{0 , 5 3 9}$ & $-0,007$ & $-0,048$ & $\mathbf{1}$ & & & & \\
\hline $\mathrm{K}$ & $\mathbf{0 , 1 3 3}$ & $\mathbf{0 , 6 7 8}$ & $-0,026$ & $-0,077$ & $\mathbf{1}$ & & & \\
\hline $\mathrm{HCO} 3$ & 0,136 & $-0,242$ & 0,099 & 0,205 & $-0,329$ & $\mathbf{1}$ & & \\
\hline $\mathrm{Cl}$ & 0,287 & 0,206 & $-0,139$ & $\mathbf{0 , 5 1 0}$ & 0,205 & $-0,243$ & $\mathbf{1}$ & \\
\hline SO4 & 0,230 & 0,339 & $\mathbf{0 , 0 4 8}$ & $\mathbf{0 , 0 2 8}$ & $\mathbf{0 , 2 0 7}$ & $-0,161$ & $-0,169$ & $\mathbf{1}$ \\
\hline
\end{tabular}

Tab. 3 Factorial coordinates

\begin{tabular}{|llll|}
\hline \multicolumn{4}{|l|}{ 2014 data } \\
\hline FD & F2 & F3 \\
\hline Ca & $\mathbf{0 , 8 3 6}$ & 0,484 & 0,258 \\
\hline Mg & 0,582 & $-0,572$ & 0,111 \\
\hline Na & $\mathbf{0 , 4 7 8}$ & 0,448 & $-0,452$ \\
\hline K & 0,496 & $-0,633$ & 0,052 \\
\hline HCO3 & $-0,125$ & $\mathbf{0 , 4 3 7}$ & 0,083 \\
\hline Cl & 0,498 & 0,004 & $-0,645$ \\
\hline SO4 & $\mathbf{0 , 2 5 4}$ & $-0,186$ & 0,241 \\
\hline
\end{tabular}

Figures 


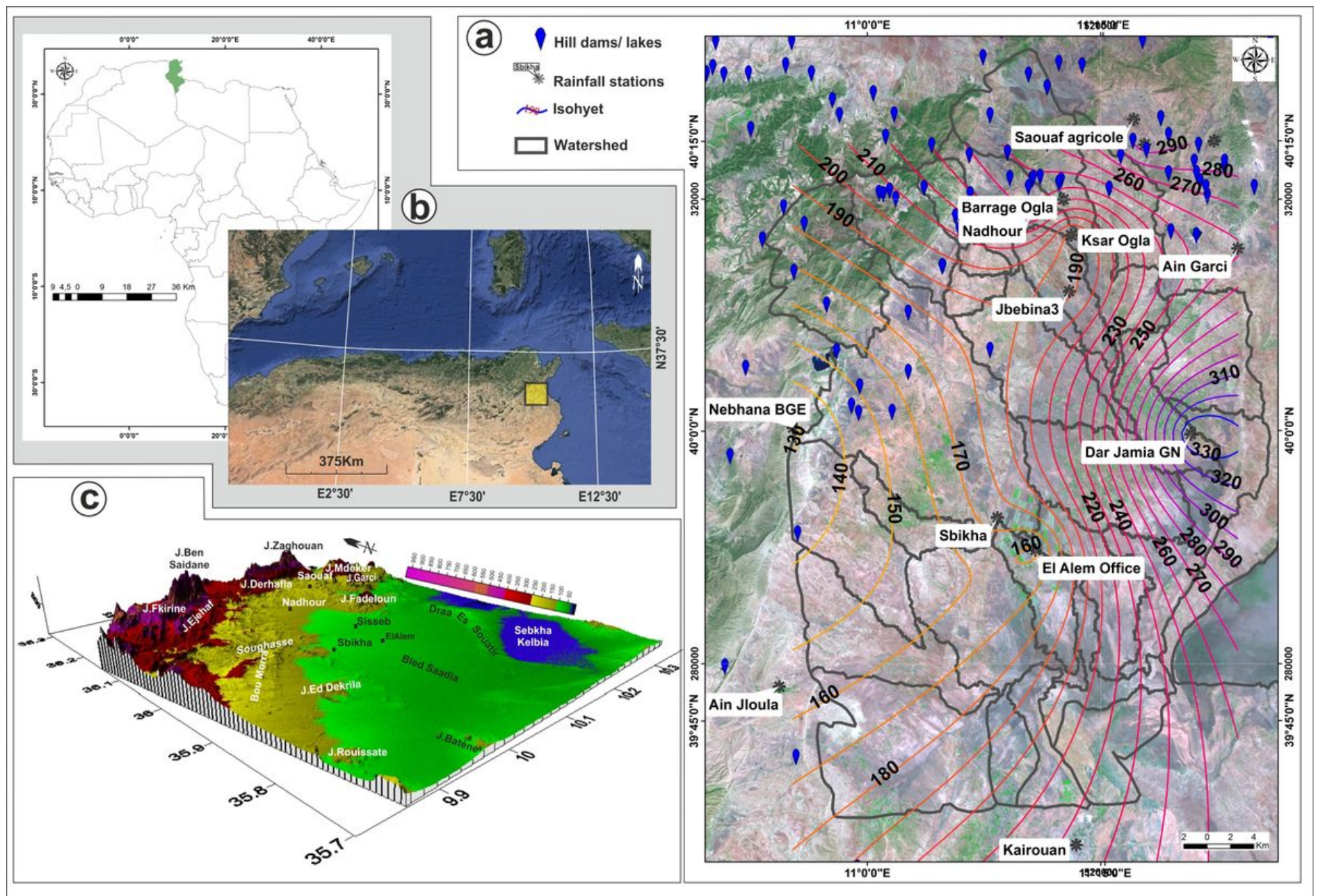

Figure 1

a Geographic setting of the study area, b This figure showing spatial distribution of rainfall and location of dam, hill dams and hilly lakes, c DTM extracted from the SRTM. Note: The designations employed and the presentation of the material on this map do not imply the expression of any opinion whatsoever on the part of Research Square concerning the legal status of any country, territory, city or area or of its authorities, or concerning the delimitation of its frontiers or boundaries. This map has been provided by the authors. 


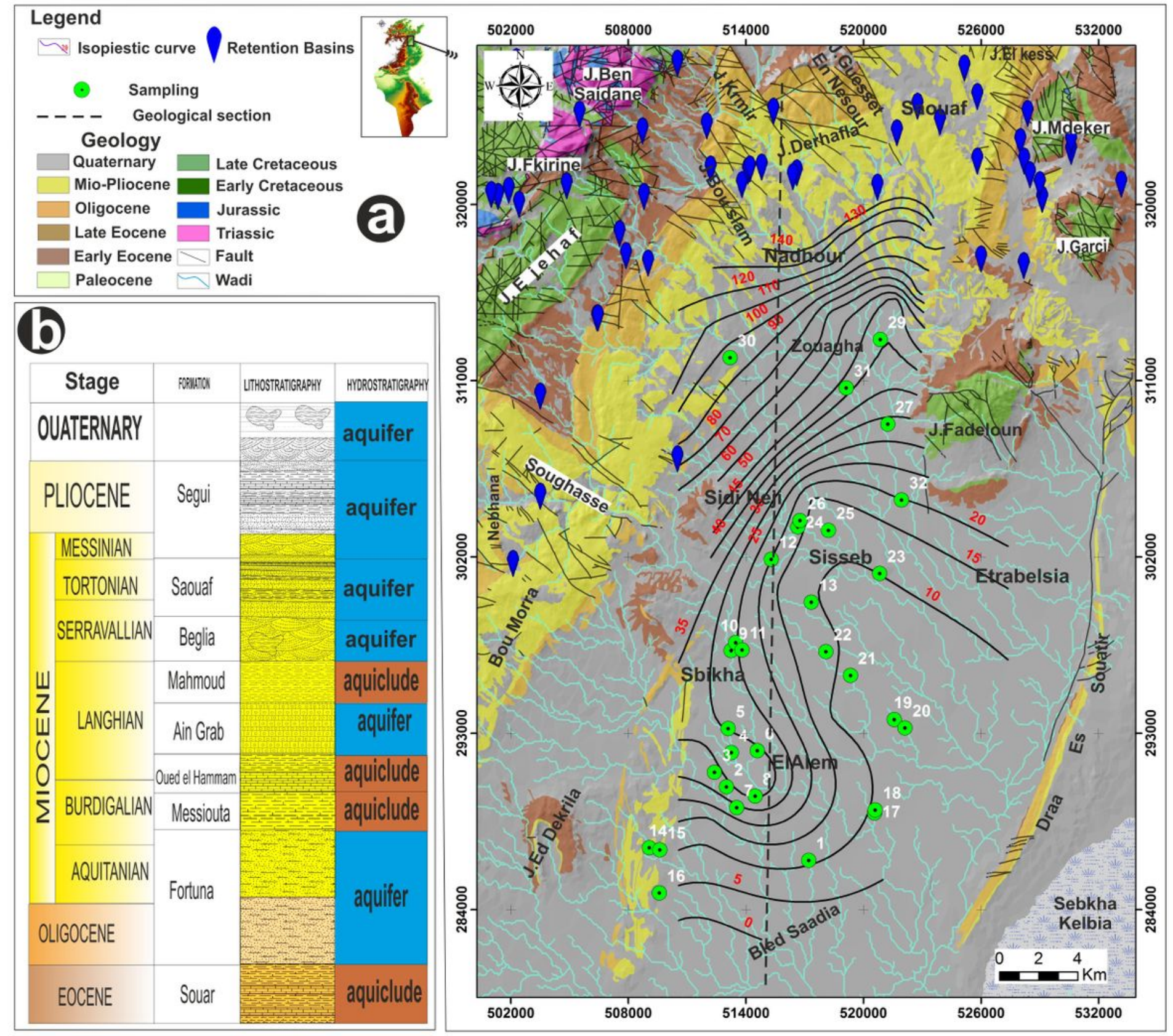

Figure 2

Geological map of the study area and Hydrostratigraphic colum, for the Eocene-Quaternary period, of the study area Note: The designations employed and the presentation of the material on this map do not imply the expression of any opinion whatsoever on the part of Research Square concerning the legal status of any country, territory, city or area or of its authorities, or concerning the delimitation of its frontiers or boundaries. This map has been provided by the authors. 


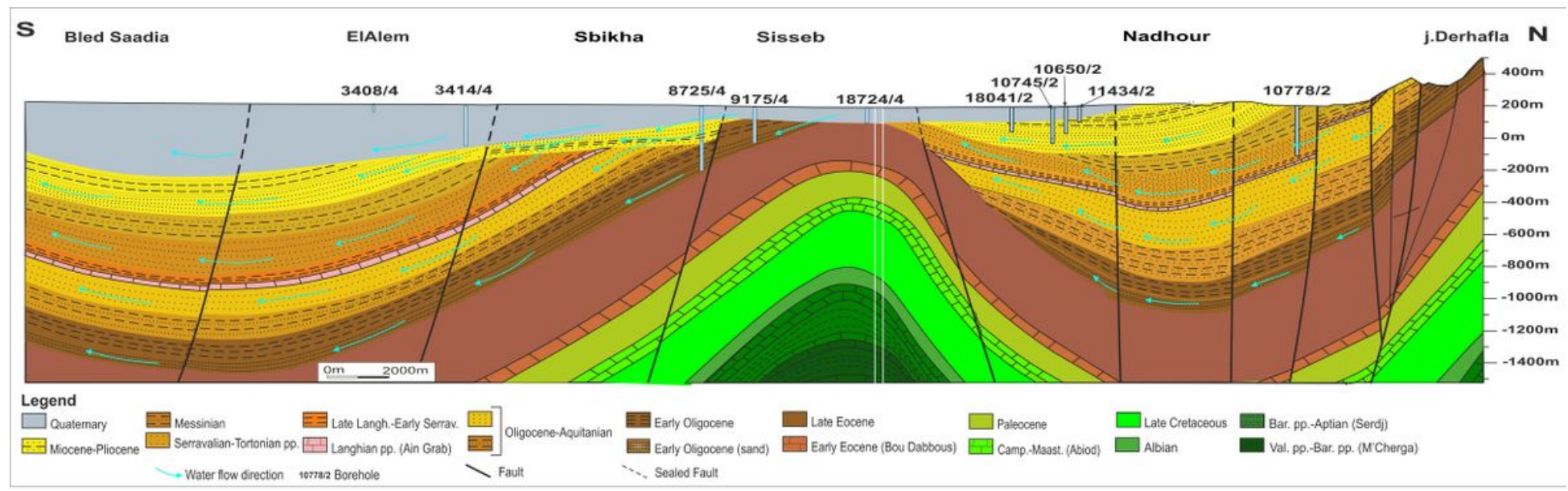

Figure 3

Geological section over the Nadhour Sisseb-El-Alem area, showing the facies and thickness variations between the main depressions and palaeohighs. (for location, see Fig. 2) Note: The designations employed and the presentation of the material on this map do not imply the expression of any opinion whatsoever on the part of Research Square concerning the legal status of any country, territory, city or area or of its authorities, or concerning the delimitation of its frontiers or boundaries. This map has been provided by the authors.

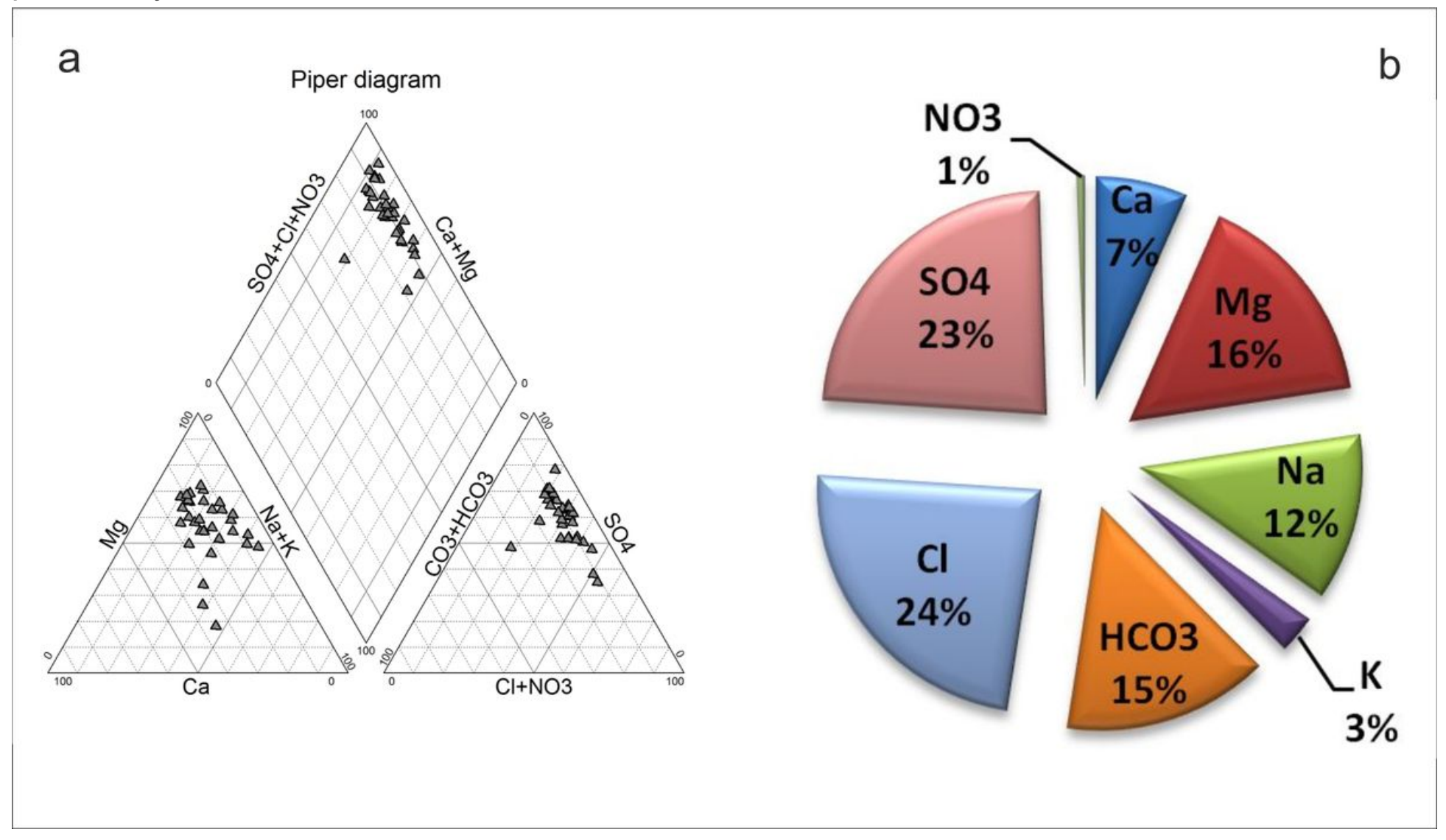

Figure 4

a; Piper Diagram of the groundwater samples, b; Pie diagram shows the abundance of major elements 


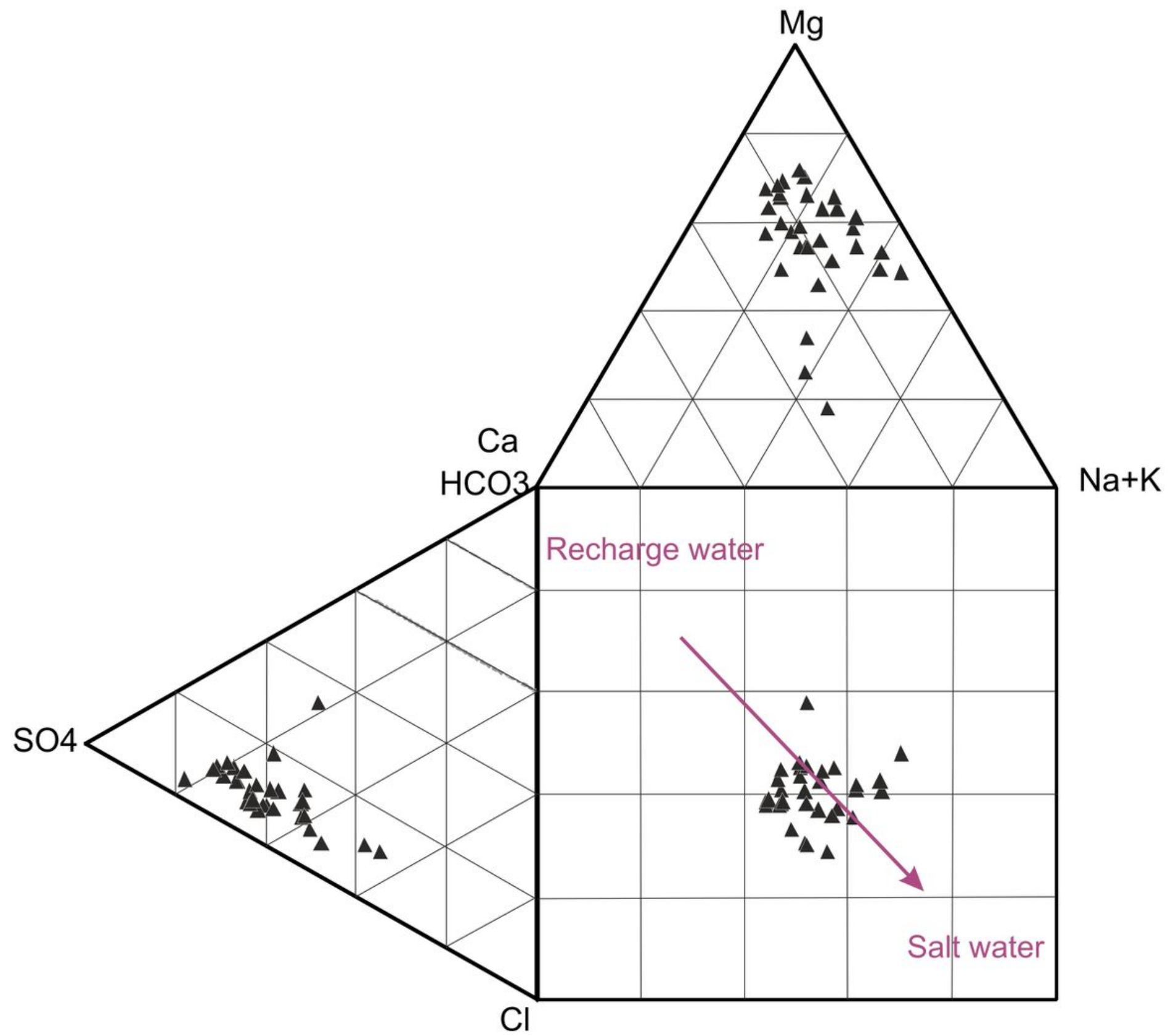

Figure 5

Classification of Groundwater hydrochemical facies based on Durov diagram 


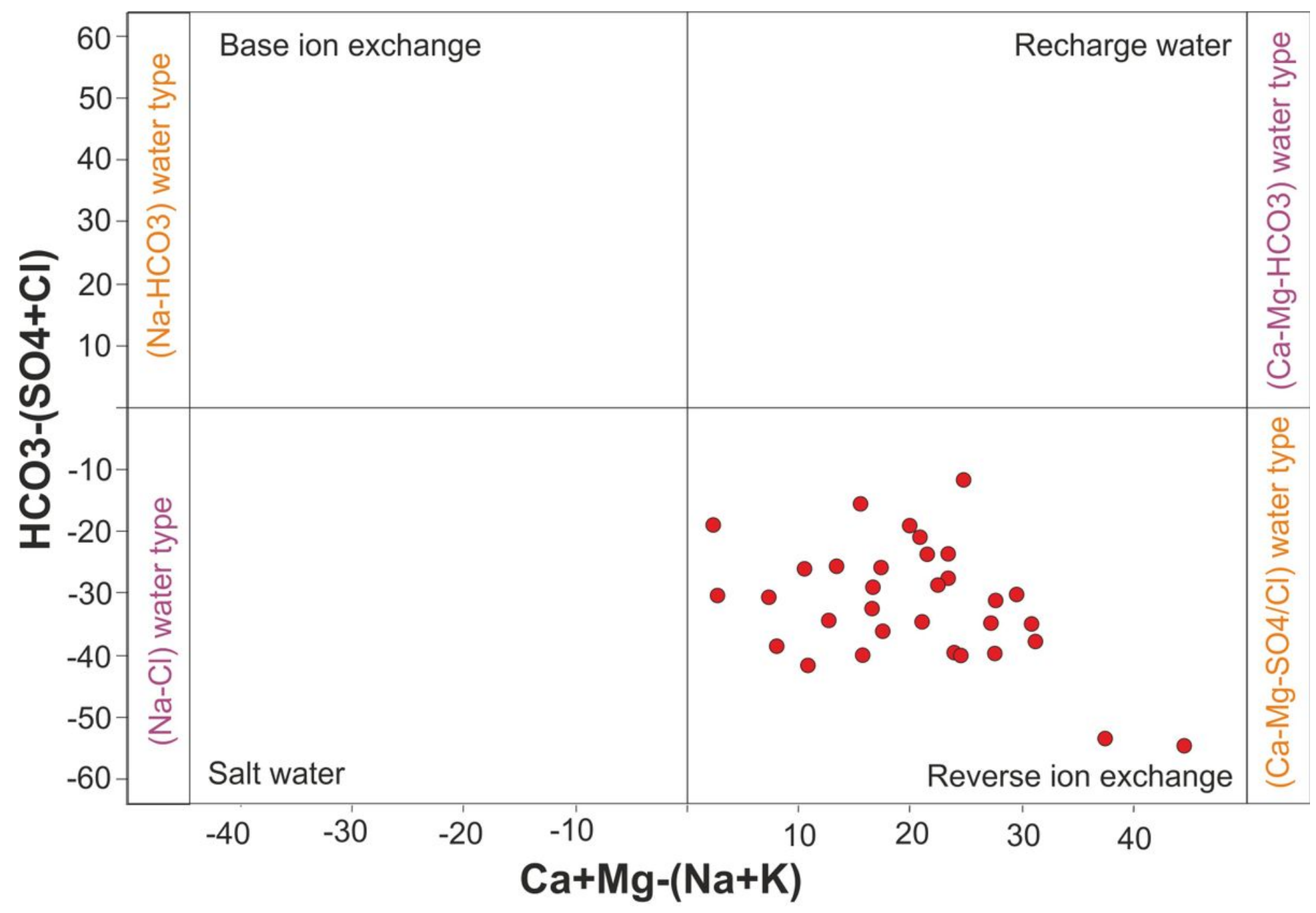

Figure 6

Groundwater hydrochemical type based on Chadha's diagram 


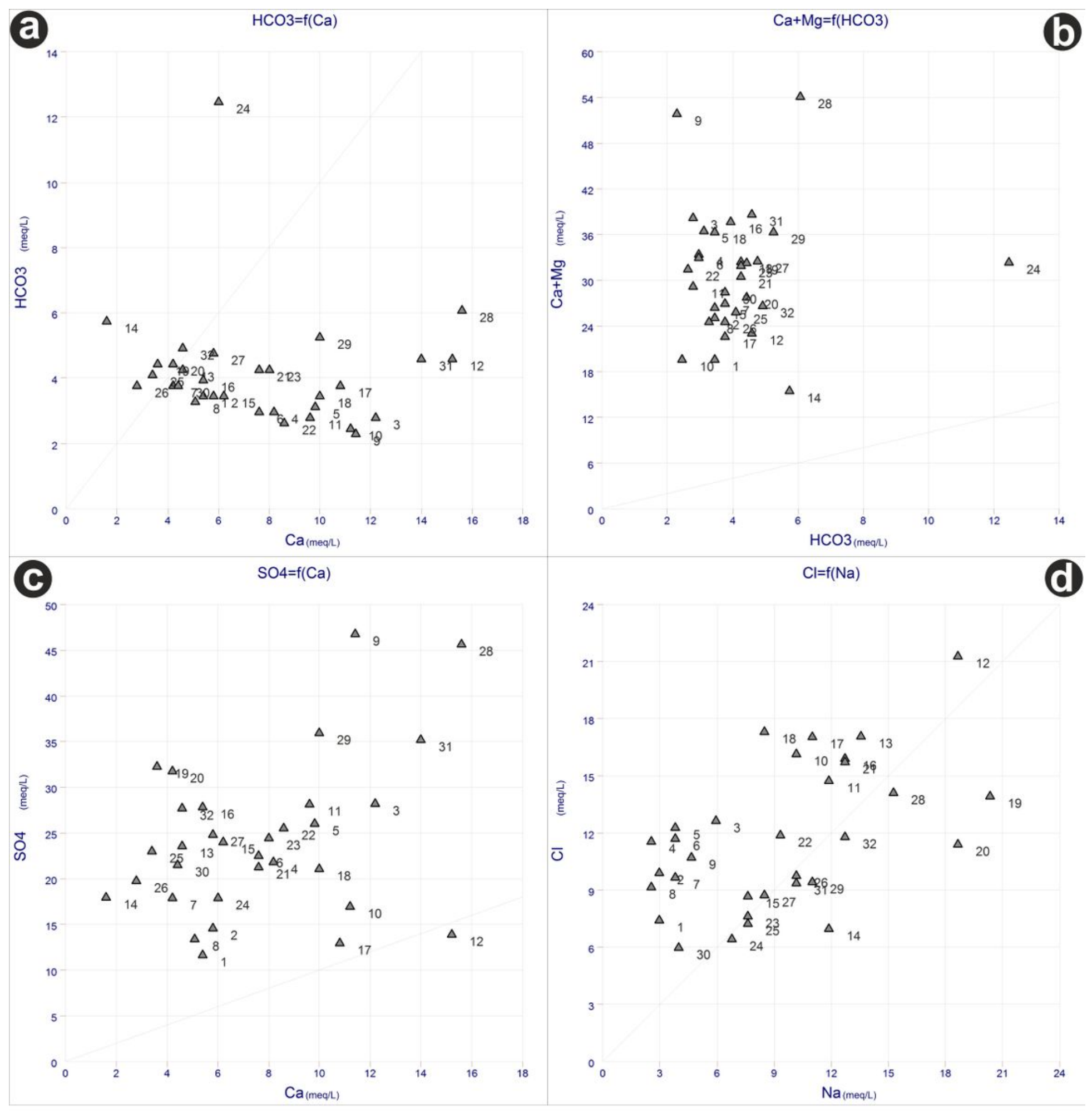

Figure 7

Correlations between major elements 


\section{Coordinate variables (axes F1 and F2: 65.94\%)}

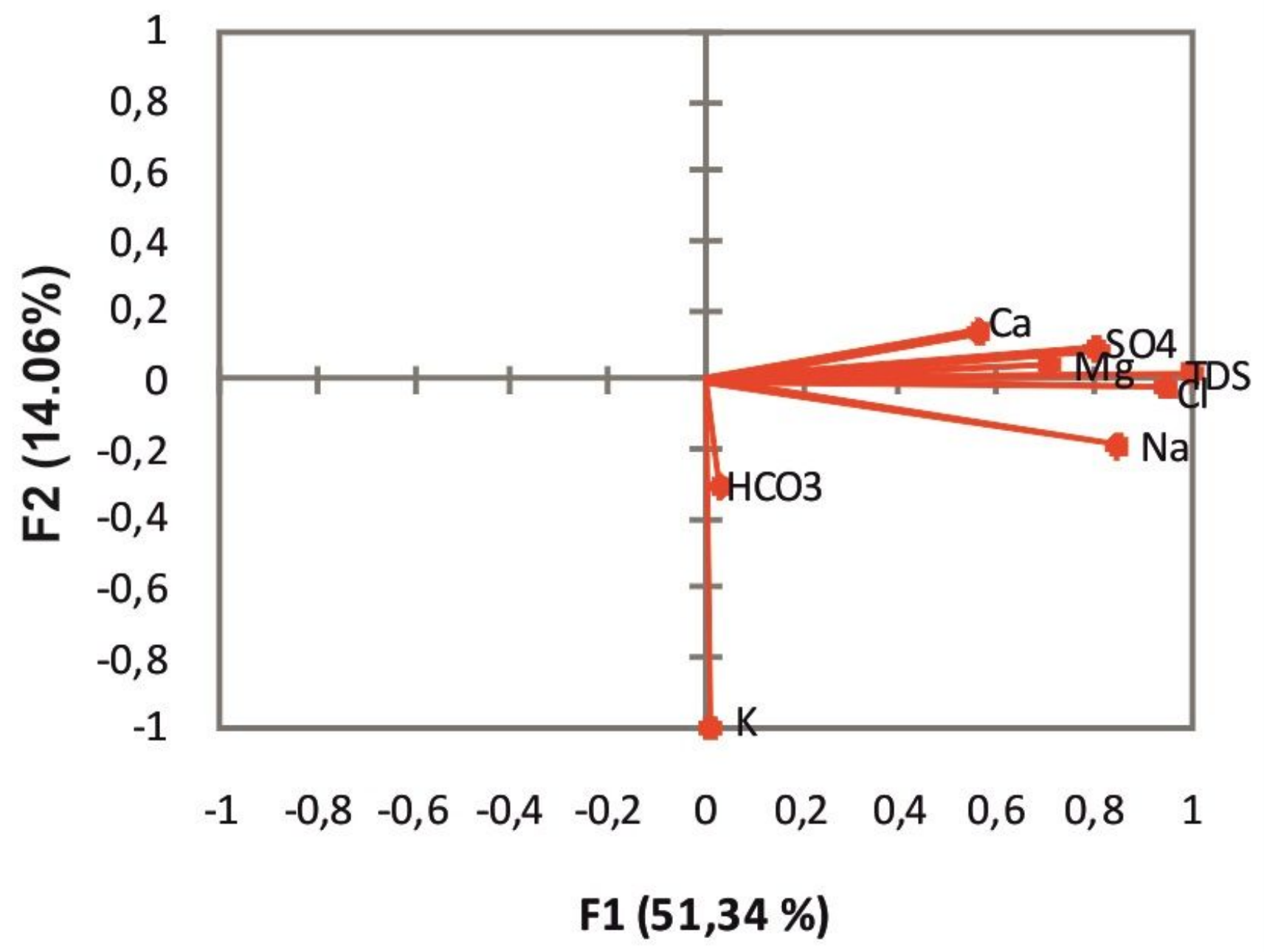

Figure 8

Factorial plan 

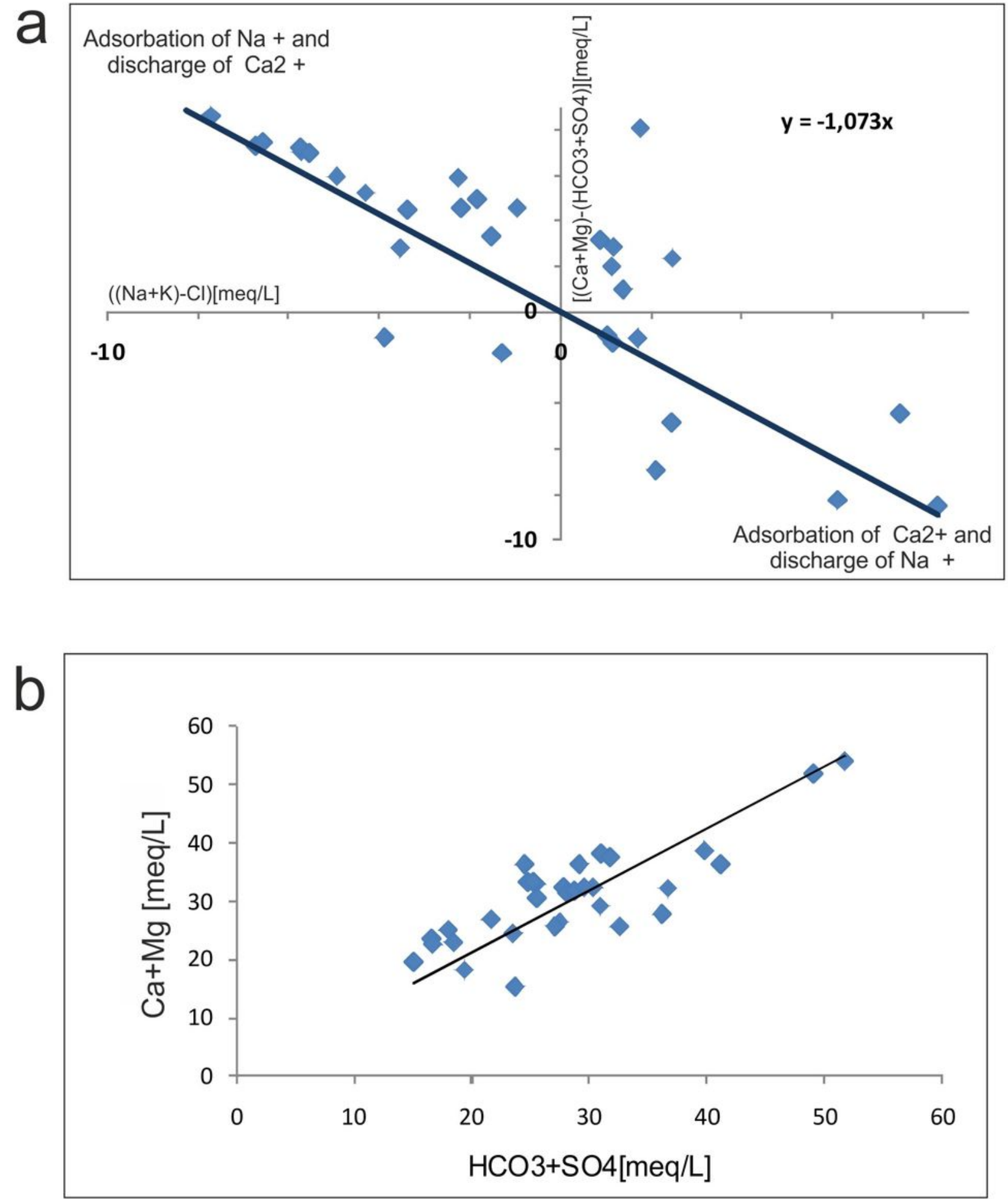

Figure 9

a; Base Exchange plot, b; $\mathrm{Ca}+\mathrm{Mg} / \mathrm{HCO} 3+\mathrm{SO} 4$ plot 


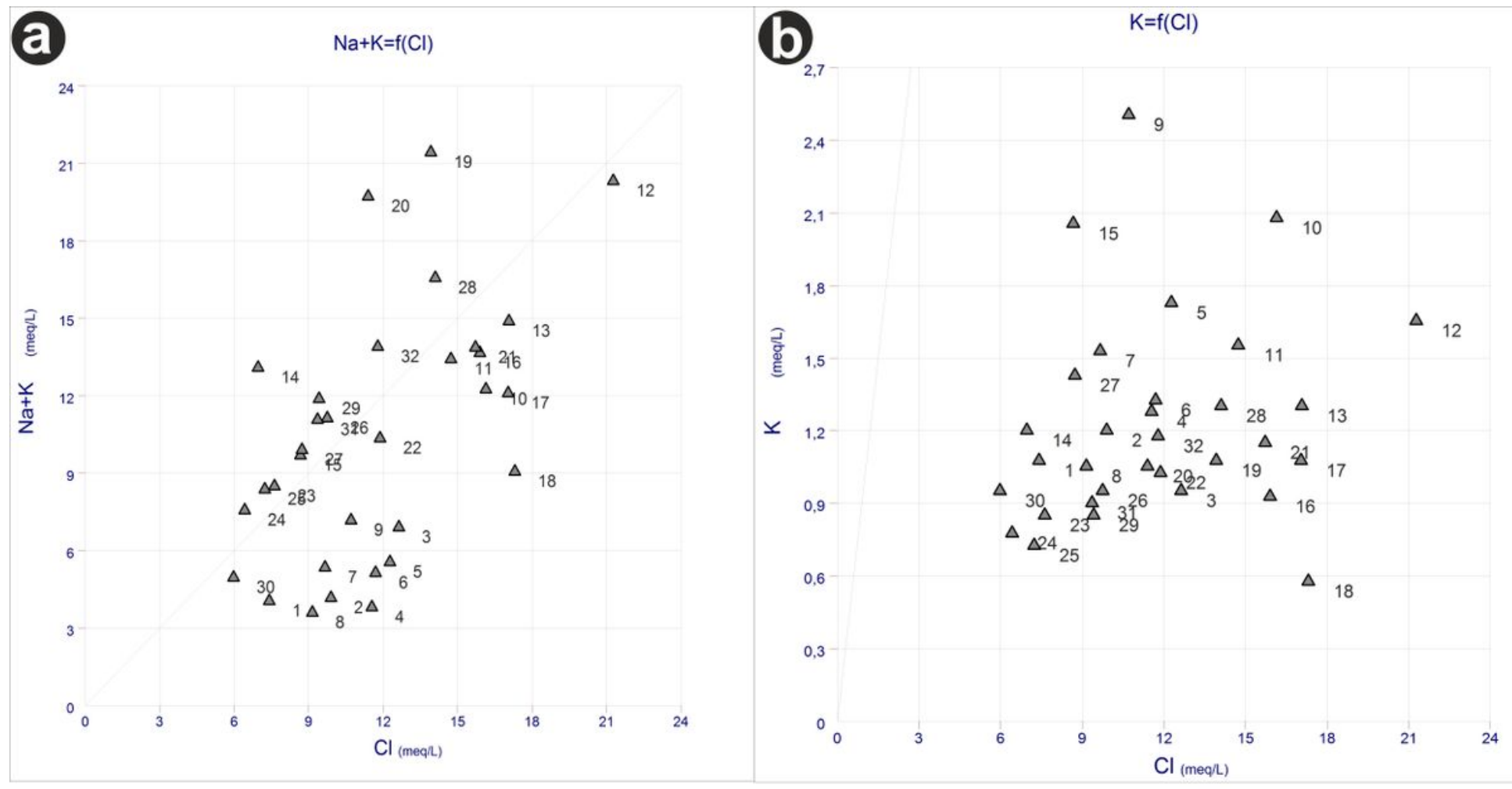

Figure 10

Correlations between major elements 


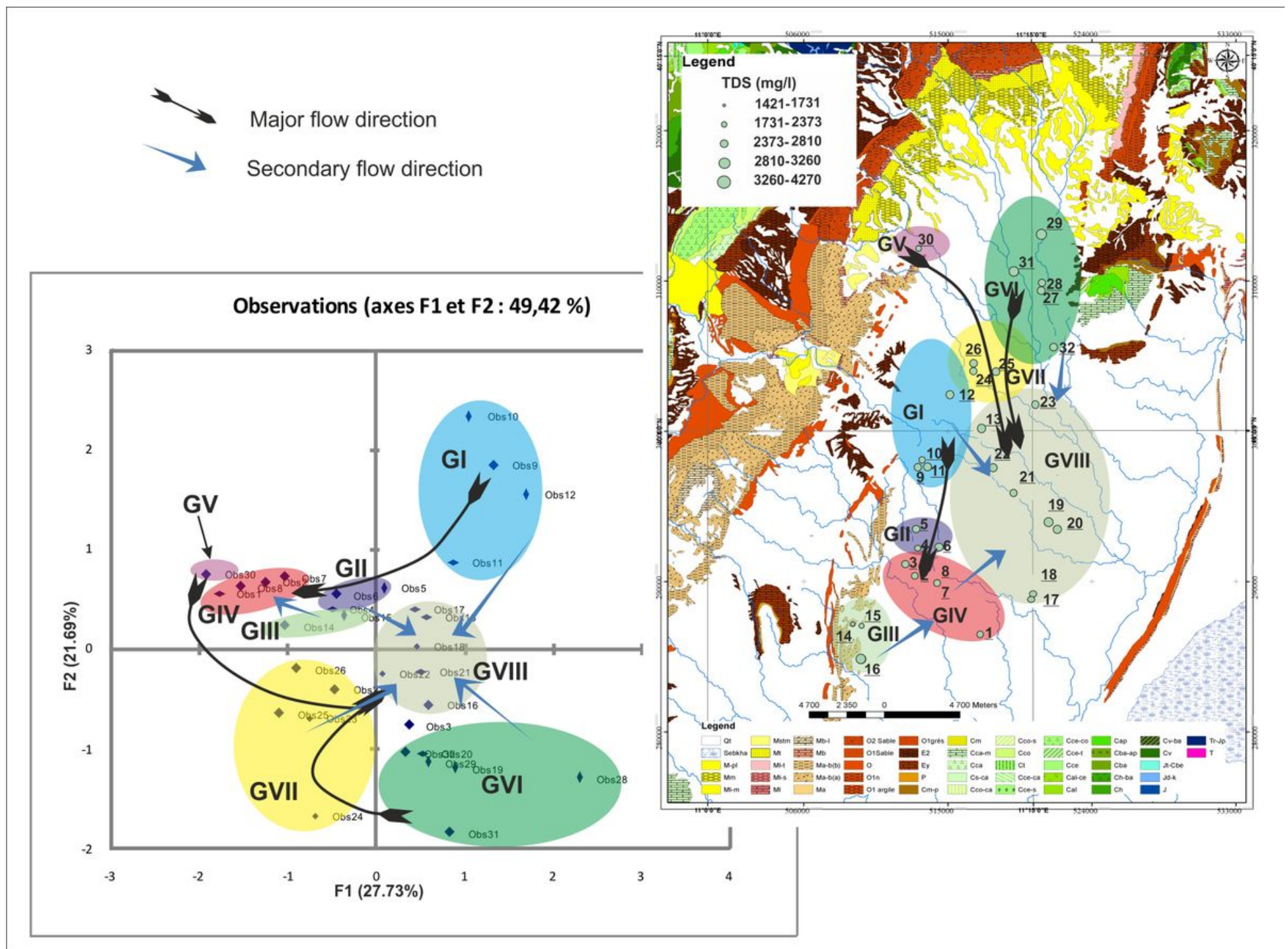

\section{Figure 11}

Implementation of samples on the F1/F2 Factorial plan shows the different groups of waters and their spatial distribution in the basin Note: The designations employed and the presentation of the material on this map do not imply the expression of any opinion whatsoever on the part of Research Square concerning the legal status of any country, territory, city or area or of its authorities, or concerning the delimitation of its frontiers or boundaries. This map has been provided by the authors. 


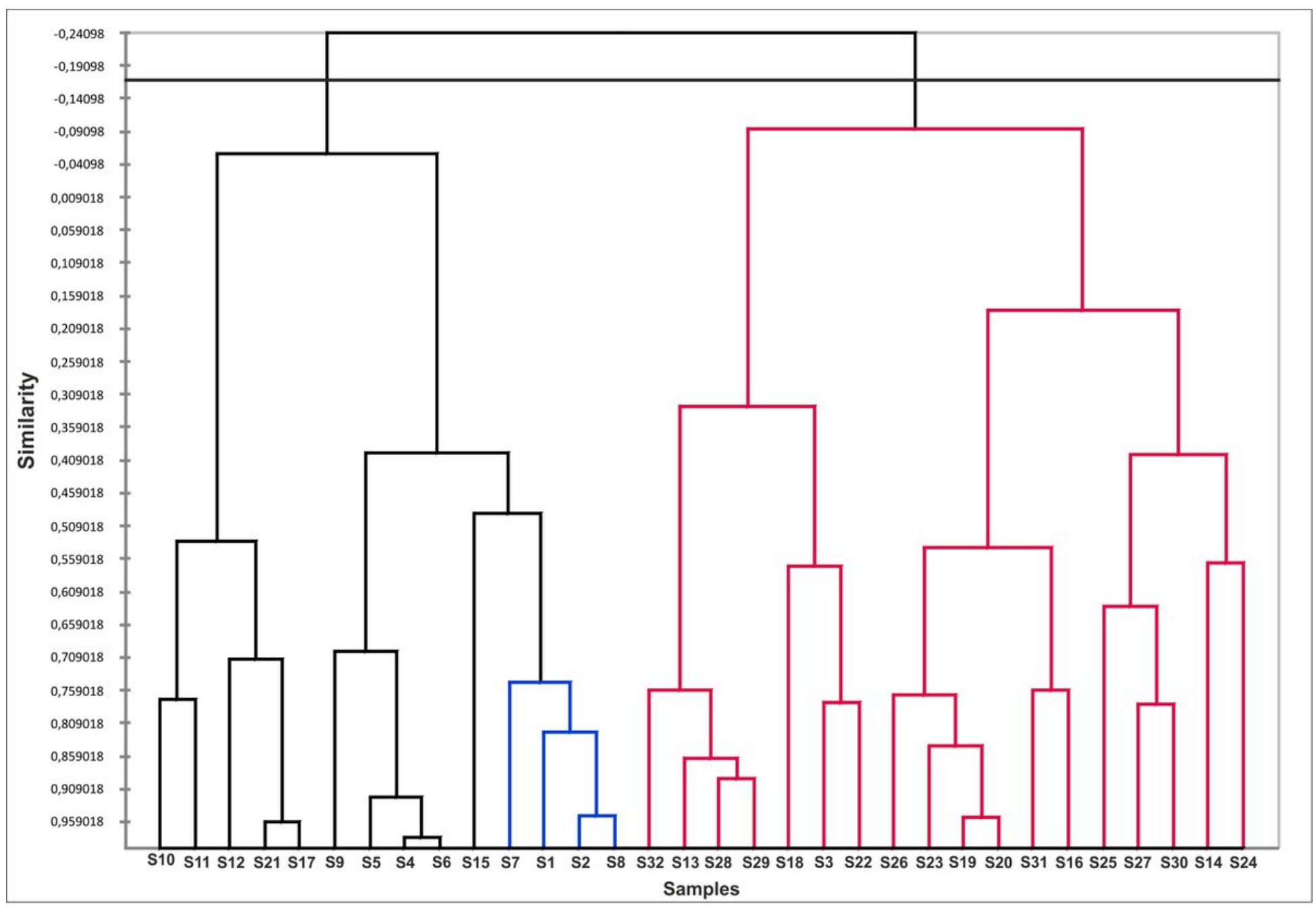

Figure 12

Dendrogram presents the cluster analysis 


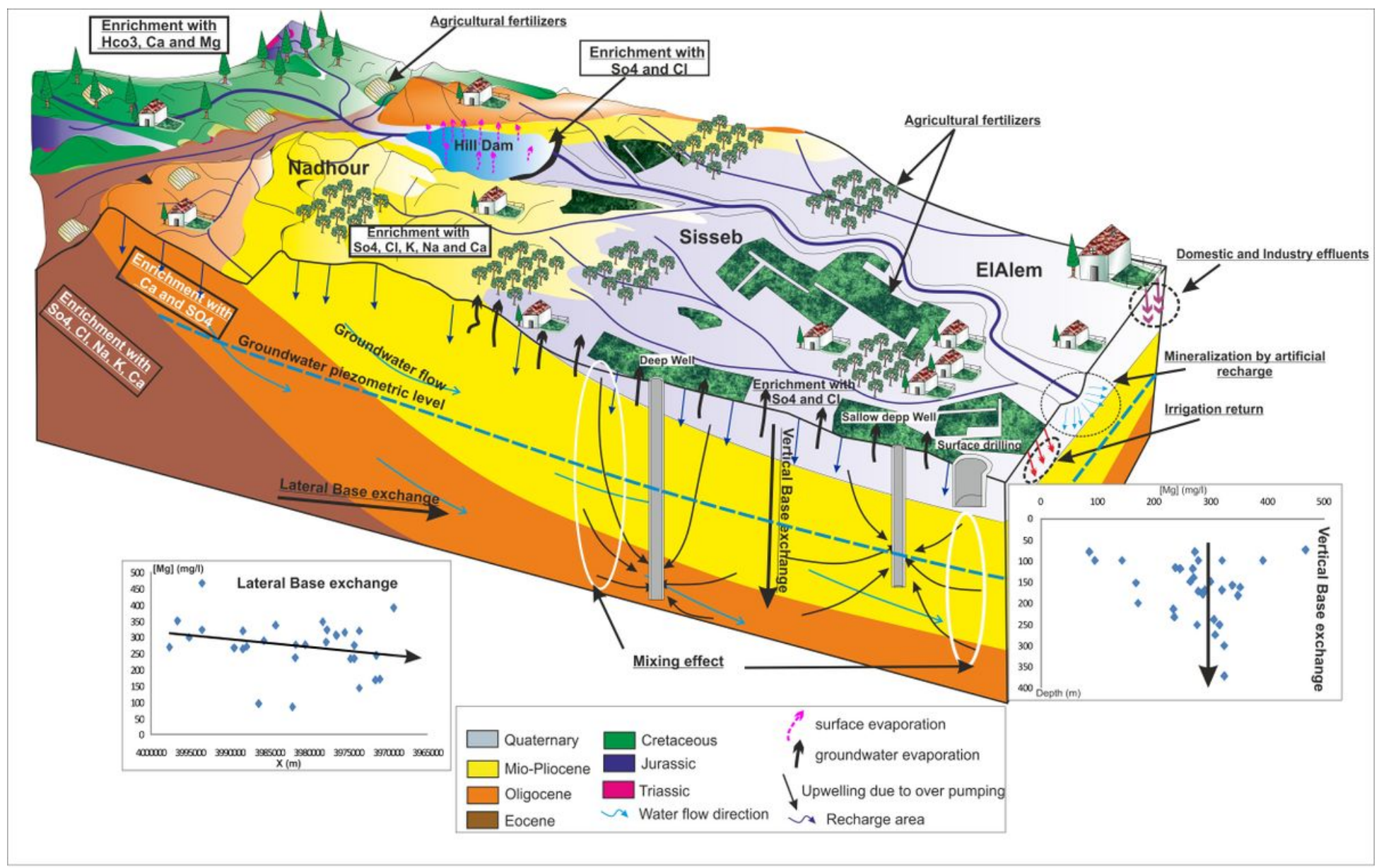

\section{Figure 13}

Mineralization conceptual model of water in the Nadhour-Sisseb-El Alem basin Note: The designations employed and the presentation of the material on this map do not imply the expression of any opinion whatsoever on the part of Research Square concerning the legal status of any country, territory, city or area or of its authorities, or concerning the delimitation of its frontiers or boundaries. This map has been provided by the authors. 